discharged but settled back to feed on the shore almost instantly-it appeared that the guns worked much better for ducks than shorebirds.

On August 10, a trip was made to the Isle of Bays with Dr. R. Connell, Dept. of Veterinary Science, University of Saskatchewan. We walked along the entire shoreline of the island and estimated roughly that 7000 birds had died. The disease (Dr. Connell was not sure whether ducks were dying from botulism or algae or a combination of both) was pretity well over by this date and less than 100 sick ducks were found.

The Zons were picked up on August 11 as the outbreak had subsided after some rain had fallen and the temperatures had dropped somewhat.
Ducks Unlimited staff have since indicated that they would be in a positicn to supply 20 of more Zons for next season should another outbreak occur. It is felt that since any of their projects which raise 10,000 ducks is considered an "excellent" project, a project which would prevent a loss of 10,000 is in reality as good as an additional project, and perhaps less costly. The Department of Natural Resources has been asked to cooperate with Ducks Unlimited in reporting promptly any outbreaks and in interesting sportsmen's groups in looking after Zons if they are requred. Various asjecis of the problem will be discussed at the Fish and Game League convention at Fort Qu'Appelle, February 11-13.

\title{
Bird Houses Project at the Saskatchewan Training School
}

By A. J. Beddie, Superintendent, Sask. Training School, Moose Jaw

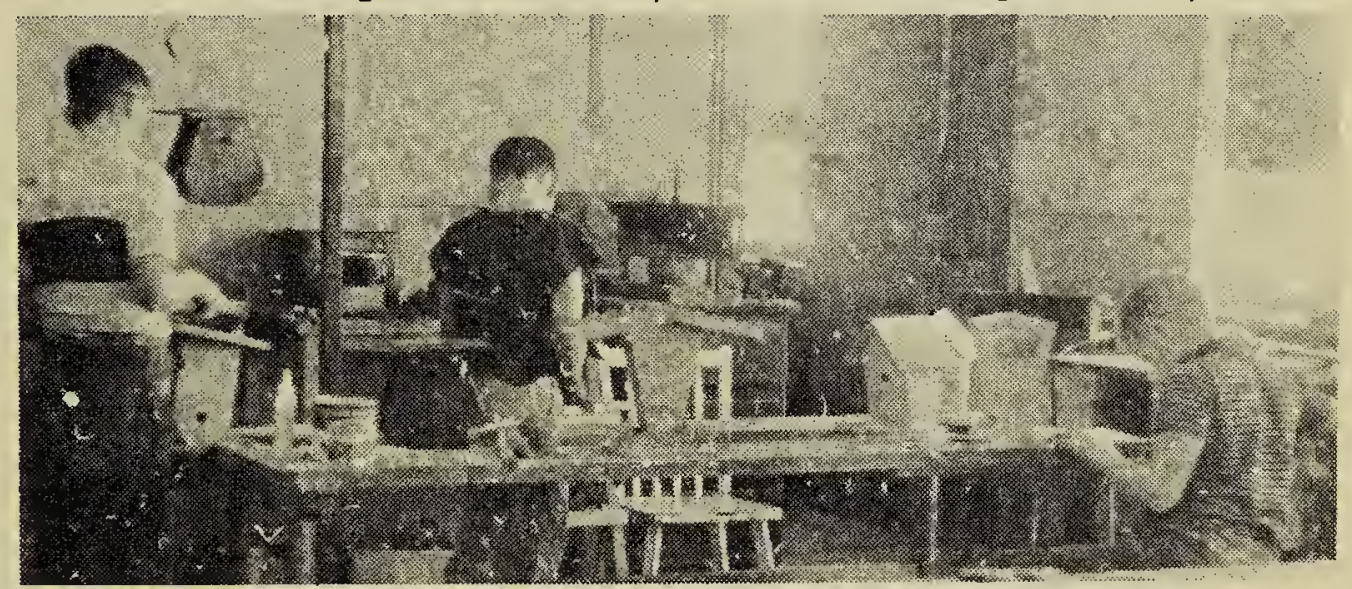

Manual Training Class at Sask. Training School

The boys in the manual training classroom at the Saskatchewan Training School have, for some time, been making bird boxes. Most of these boxes are of a comparatively simple design because interested purchasers wished this type.

The Moose Jaw Natural History Society has a spring project of placing bird boxes and feeding stations in the local parks and is encouraging citizens to do the same. The Society contacted the Training School to ask for boxes and stations to suit the needs of different species. It is hoped to make colony nests for martins, and suitable nests for swallows, wrens and bluebirds. The variety of sizes and designs adds considerable interest to the making, and stimulates an interest in the different birds.
We hope to have boxes around the School which will be of value to the pupils in their nature studies.

Mr. Bard, Director of the Saskatchewan Museum of Natural History, visited the School last fall and expressed interest in the boys' work and very kindly offered to help dispose of their boxes at the Museum. We are most grateful for this offer since it adds purpose to the boys' work, and gives incentive to making a more finished product.

The bird nesting boxes will sell for $\$ 1.00$ to $\$ 2.50$ for simple basic types, with more elaborate houses proportionately priced. The price of the projected martin colony house will be around $\$ 20.00$. Some feeders (selffeed) are available at $\$ 2.50$ Shipping charges extra. Write Dr.A. J. Beddie, Sask. Training School, Moose Jaw. 